\title{
PENGARUH PROBLEM-BASED LEARNING TERHADAP HASIL BELAJAR DITINJAU DARI MOTIVASI BELAJAR PLC DI SMK
}

\author{
Bekti Wulandari \\ Pendidikan Teknik Informatika FT UNY \\ be.wulandari@gmail.com \\ Herman Dwi Surjono \\ Program Pascasarjana Universitas Negeri Yogyakarta \\ hermansurjono@uny.ac.id
}

\begin{abstract}
Abstrak
Penelitian ini bertujuan untuk mengetahui: (1) perbedaan hasil belajar siswa pada mata pelajaran pemrograman sistem kendali PLC antara siswa yang diajar dengan metode PBL dengan siswa yang diajar dengan metode demonstrasi, (2) pengaruh interaksi antara metode PBL dan metode demonstrasi dengan motivasi belajar terhadap hasil belajar siswa, (3) perbedaan hasil belajar siswa antara siswa yang diajar dengan metode PBL dengan yang diajar dengan metode demonstrasi ditinjau dari motivasi belajar. Penelitian ini merupakan penelitian eksperimen semu dengan desain faktorial yang dilakukan dengan memberikan perlakuan metode pembelajaran. Analisis data dalam penelitian ini menggunakan uji-t dan ANAVA dengan program SPSS 16. Hasil penelitian menunjukkan bahwa: (1) terdapat perbedaan hasil belajar antara siswa yang diajar dengan metode PBL dengan yang diajar dengan metode demonstrasi, (2) tidak terdapat pengaruh interaksi antara metode PBL dan demonstrasi dengan motivasi belajar terhadap hasil belajar, (3) terdapat perbedaan hasil belajar antara siswa yang diajar dengan metode PBL dengan yang diajar dengan metode demonstrasi ditinjau dari motivasi tinggi dan rendah.
\end{abstract}

Kata kunci: metode pembelajaran, Problem-Based Learning, motivasi belajar, hasil belajar

\section{THE EFFECT OF PROBLEM-BASED LEARNING ON THE LEARNING OUTCOMES SEEN FROM MOTIVATION ON THE SUBJECT MATTER OF PLC IN SMK}

\begin{abstract}
This study aimed to determine: (1) the difference in learning outcomes in the subject of PLC control system programming between the students taught using the PBL method and those taught using the demonstration method, (2) the effect of the interaction among the PBL method and demonstration learning method with motivation on the learning outcomes, (3) difference in students' learning outcomes between the students taught using the PBL method and those taught using the demonstration learning method in terms of motivation to learn. This study was a quasiexperimental study with a factorial design done by giving treatment in learning methods. The techniques of data analysis were T test and analysis of variance (ANOVA) with SPSS 16. The results show that: (1) there is a difference in learning outcomes between the students taught using the PBL method compared to those taught using the demonstration learning method, (2) there is no interactional effect between PBL and demonstration learning methods with motivation on the students' learning outcome, (3) there is a difference in the learning outcome between students taught using the PBL method and those taught using the demonstration learning method in terms of students with high and low motivation.
\end{abstract}

Keywords: learning methods, problem-based learning, motivation to learn, learning outcomes. 


\section{PENDAHULUAN}

Sekolah Menengah Kejuruan (SMK) merupakan lanjutan pendidikan menengah pertama yang mempunyai tujuan utama menyiapkan tenaga kerja yang terampil, profesional, dan berdisiplin tinggi sesuai dengan tuntutan dunia kerja. Tujuan tersebut tercantum dalam UU Sisdiknas pasal 15 dimana menyebutkan tujuan khusus SMK adalah menyiapkan siswa agar menjadi manusia produktif, mampu bekerja mandiri, mengisi lowongan pekerjaan yang ada di dunia usaha dan dunia industri sebagai tenaga kerja tingkat menengah sesuai dengan kompetensi dalam program keahlian yang dipilihnya. Salah satu usaha untuk mewujudkannya adalah meningkatkan kualitas pembelajaran.

Pembelajaran merupakan suatu proses interaksi antara guru dan siswa beserta unsur yang ada di dalamnya. Guru merupakan faktor yang paling dominan yang menentukan kualitas pembelajaran. Kualitas pembelajaran yang baik, tentu akan menghasilkan hasil belajar yang baik pula. Menurut Rusman (2012: 148) dalam sistem pembelajaran guru dituntut untuk mampu memilih metode pembelajaran yang tepat, mampu memilih dan menggunakan fasilitas pembelajaran, mampu memilih dan menggunakan alat evaluasi, mampu mengelola pembel-ajaran di kelas maupun di laboratorium, menguasai materi, dan memahami karakter siswa. Salah satu tuntutan guru tersebut adalah mampu memilih metode pembelajaran yang tepat untuk mengajar. Apabila metode pembelajaran yang digunakan guru itu tepat maka pencapaian tujuan pembelajaran akan lebih mudah tercapai, sehingga nilai ketuntasan belajar siswa akan meningkat, minat dan motivasi belajar siswa juga akan meningkat dan akan tercipta suasana pembelajaran yang menyenangkan.

Sesuai dengan Keputusan Direktur Jenderal Manajemen Pendidikan Dasar dan Menengah Departemen Pendikan Nasional Nomor 251/C/KEP/MN/2008 tentang Spektrum Keahlian Pendidikan Menengah Kejuruan bahwa SMK terdapat enam Bidang Studi Keahlian yang terbagi dalam enam belas Program Studi Keahlian dan seratus dua puluh satu kompe-tensi keahlian dengan masa pendidikan adalah 3 (tiga) tahun atau dapat diperpanjang sampai 4 (empat) tahun setelah pendidikan dasar. Kompetensi Keahlian Elektronika
Industri merupakan salah satu dari seratus dua puluh satu kompetensi keahlian tersebut dengan program studi keahlian Teknik Elektronika.

Di setiap Kompetensi Keahlian terdiri dari beberapa kompetensi. Pemrograman sistem kendali PLC sebagai satu bagian mata pelajaran pada Kompetensi Keahlian tersebut. Mata pelajaran pemrograman sistem kendali PLC merupakan mata pelajaran komponen kejuruan dan termasuk dalam kelompok mata pelajaran produktif yang harus dikuasai oleh semua lulusan SMK kompetensi keahlian Elektronika Industri. Mata pelajaran pemrograman sistem kendali PLC ini diberikan kepada siswa kompetensi keahlian industri pada saat siswa kelas XI. Selama ini sistem kendali di dalam dunia industri sering menggunakan sistem kendali PLC sehingga ma-ta pelajaran pemrograman sistem kendali PLC penting untuk dikuasai siswa guna menyiapkan kompetensi sesuai dengan kebutuhan industri. Kompetensi yang harus dikuasai siwa adalah mendeskripsikan ladder diagram pada pemrograman PLC; memprogram PLC dengan menggunakan konsole dan komputer; menggunakan bahasa pemrograman yang dapat berinteraksi dengan I/O pada sistem komputer; menginstalasi kerja sistem pengendali elektronik berbantuan PLC dan komputer dengan sensor, transduser, dan penggerak; mengoperasikan kerja sistem pengendali elektronik berbantuan PLC dan komputer dengan sensor, transduser, dan penggerak; menguji kerja sistem pengendali elektronik berbantuan PLC dan komputer dengan sensor, transduser, dan penggerak; dan membuat dokumentasi.

Hasil wawancara dengan guru mata pelajaran pemrograman sistem kendali PLC pada tanggal 12 Juli 2012, diperoleh informasi tentang hasil ulangan kenaikan kelas siswa pada mata pelajaran pemrograman sistem kendali PLC tahun ajaran 2011/2012 di SMK N 3 Wonosari. Dari hasil tersebut masih banyak siswa yang nilainya dibawah Kriteria Ketuntasan Minimal (KKM). Data Persentase dari empat (4) kelas EI SMK N 3 Wonosari disajikan pada Tabel 1.

Siswa yang masih di bawah KKM dilakukan remidi. Dari hasil survey, siswa yang nilainya masih kurang hanya diberikan soal tanpa memberikan materi pembelajaran kepada siswa yang belum paham atau menguasai kompetensi yang telah diberikan. Sebaiknya 
pelaksanaan remidi tidak hanya melakukan ujian ulang saja, akan tetapi melakukan pembelajaran ulang, sehingga kompetensi yang belum dipahami siswa akan dapat dipahami dengan baik. Akan tetapi, pelaksanaan remidi tentu saja akan membutuhkan tambahan waktu dan akan menambah suatu masalah baru ketika pelaksanaan jadwal semester akan berakhir dan berganti dengan semester berikutnya dan guru dituntut untuk segera menyelesaikan administrasi mengajarnya. Untuk itu dibutuhkan suatu metode pembelajaran yang tepat agar siswa dapat belajar dengan maksimal dan mendapatkan nilai yang maksimal sehingga tidak banyak siswa yang nilainya di bawah KKM.

Tabel 1. Persentase Nilai Ulangan Kenaikan Kelas

\begin{tabular}{lcc}
\hline Kelas & $\geq$ KKM & $<$ KKM \\
\hline XI EI 1 & $32,26 \%$ & $67,4 \%$ \\
XI EI 2 & $14,7 \%$ & $85,3 \%$ \\
XI EI 3 & $14,3 \%$ & $85,7 \%$ \\
XI EI 4 & $0 \%$ & $100 \%$ \\
\hline
\end{tabular}

Perolehan hasil belajar yang masih banyak di bawah KKM ini dipengaruhi oleh beberapa faktor, salah satunya adalah motivasi belajar siswa. Motivasi belajar merupakan dorongan yang timbul dari dalam dan luar individu untuk melakukan perubahan tingkah laku. Motivasi belajar yang ada dalam diri siswa yang satu dengan yang lain berbeda-beda, ada siswa yang motivasi belajarnya tinggi dan ada juga yang motivasi belajarnya rendah.

Nilai hasil belajar siswa yang belum maksimal juga dapat disebabkan karena lemahnya kualitas pembelajaran. Berdasarkan observasi yang dilakukan, dalam proses pembelajaran masih berorientasi pada penyelesaian tugas yang dirancang oleh guru dan dengan cara mengajar guru yang masih konvensional. Dominasi guru yang sangat kuat membuat terabaikannya kesempatan siswa untuk terlibat aktif dalam pembelajaran sehingga siswa kurang kreatif. Kegiatan siswa hanya memperhatikan guru yang sedang mendemostrasikan materi pelajaran serta mencatat hal-hal yang sekiranya penting. Selain itu, dalam pembelajaran, siswa dihadapkan pada tugas pemrograman yang sudah ada di dalam jobsheet.
Tugas tersebut dikerjakan secara berkelompok dan sudah didemonstrasikan oleh guru sehingga siswa kurang mengetahui keautentikan tugas yang diberikan.

Salah satu upaya untuk memperbaiki kualitas pembelajaran dari segi guru adalah dengan mengubah metode pembelajarannya. Mata pelajaran pemrograman sistem kendali PLC merupakan mata pelajaran yang menggunakan kumpulan instruksi atau perintah yang disusun sedemikian rupa sehingga mempunyai urutan nalar yang tepat untuk menyelesaikan suatu permasalahan. Sehingga salah satu metode pembelajaran yang diduga dapat meningkatkan keaktifan dan hasil belajar siswa pada mata pelajaran pemrograman sistem kendali PLC adalah Problem Based Learning (PBL). Menurut Arends (2008:41), $P B L$ merupakan pembelajaran yang memiliki esensi berupa menyuguhkan berbagai situasi bermasalah yang autentik dan bermakna kepada siswa. Sebagai tambahan, dalam $P B L$ peran guru adalah menyodorkan berbagai masalah autentik sehingga jelas bahwa dituntut keaktifan siswa untuk dapat menyelesaikan masalah tersebut. Setelah masalah diperoleh maka selanjutnya melakukan perumusan masalah, dari masalah masalah tersebut kemudian dipecahkan secara bersama sama dengan didiskusikan. Saat pemecahan masalah tersebut akan terjadi pertukaran informasi antara siswa yang satu dengan yang lainnya sehingga permasalahan yang telah dirumuskan dapat terpecahkan. Sumber informasi tidak hanya dari guru akan tetapi dapat dari berbagai sumber. Guru disini berperan sebagai fasilitator untuk mengarahkan permasalahan sehingga saat diskusi tetap fokus pada tujuan pencapaian kompetensi.

Hasil belajar merupakan representasi pencapaian kompetensi siswa yang nantinya digunakan siswa untuk masuk ke dunia kerja. Sehingga pemilihan metode $P B L$ diharapkan mampu meningkatkan hasil belajar siswa. Dengan demikian peneliti ingin melihat pengaruh metode $P B L$ terhadap hasil belajar ditinjau dari motivasi belajar siswa pada mata pelajaran pemrograman sistem kendali PLC di SMK Negeri 3 Wonosari.

\section{Metode pembelajaran}

Istilah pembelajaran saat ini banyak digunakan dan menggantikan istilah-istilah sebelumnya seperti pengajaran atau belajar- 
mengajar yang lebih bersifat sebagai aktivitas yang berfokus pada guru. Pembelajaran adalah serangkaian aktivitas yang sengaja diciptakan dengan maksud untuk memudahkan terjadinya proses belajar pada siswa. Hal ini sejalan dengan dengan pernyataan (Gagne, Briggs \& Wager pada Winataputra (2008:19); Trianto (2009:17); Hariyanto dan Suyono (2011:209).

Rusman (2012:93) mengemukakan bahwa pembelajaran dilihat sebagai sebuah sistem yang terdiri dari berbagai komponen yang berhubungan satu dengan yang lain. Komponen tersebut meliputi tujuan, materi, metode, dan evaluasi. Metode merupakan upaya untuk mengimplementasikan rencana yang sudah disusun dalam kegiatan nyata untuk mencapai tujuan (Robert Heinich, Michael Molenda dan James D Russel (1989:7)). Metode merupakan prosedur pembelajaran yang dipilih guru untuk membantu siswa dalam mencapai tujuan pembelajaran agar tercapai secara baik dan maksimal. Metode pembelajaran adalah serangkaian aktivitas yang disengaja dengan mendesain, mengembangkan, mengimplementasikan, dan mengevaluasi dengan metode tertentu guna memfasilitasi siswa dengan tujuan mencapai suatu kompetensi.

\section{Metode Problem-Based Learning}

Metode $P B L$ merupakan metode pembelajaran dengan menghadapkan siswa pada permasalahan-permasalahan dunia nyata (Maggi Savin dan Claire Howell (2004:8); Barbara (2001:1); Linda Torp dan Sara Sage (2002:15); Tan (2003:7); Glazer (2001)). PBL merupakan pembelajaran aktif progresif dan pendekatan pembelajaran berpusat pada masalah yang tidak terstruktur yang digunakan sebagai titik awal dalam proses pembelajaran. PBL menggunakan berbagai macam kecerdasan yang diperlukan untuk melakukan konfrontasi terhadap tantangan dunia nyata, kemampuan untuk menghadapi segala sesuatu yang baru dan masalah-masalah yang dimunculkan. $P B L$ sering dilakukan dengan pendekatan tim melalui penekanan pada pembangunan keterampilan yang berkaitan dengan pengambilan keputusan, diskusi, pemeliharaan tim, manajemen konflik, dan kepemimpinan tim. Menurut Howard Barrows dan Kelson (Amir 2009:21), $P B L$ adalah kurikulum dan proses pembelajaran. Dalam kurikulumnya, dirancang masalah-masalah yang menuntut siswa mendapatkan pengetahuan yang penting, membuat mereka mahir dalam memecahkan masalah, dan memiliki strategi belajar sendiri serta berpartisipasi dalam tim. Proses pembelajarannya menggunakan pendekatan yang sistematik untuk memecahkan masalah atau menghadapi tantangan yang nanti diperlukan di dalam kehidupan sehari-hari.

Jadi $P B L$ adalah pemberian masalah yang berhubungan dengan kehidupan seharihari kepada siswa kemudian siswa secara berkelompok mencari alternatif solusi untuk menyelesaikan masalah tersebut. Sedangkan menurut Dutch (dalam Amir 2009:21) problem based learming merupakan metode instruksional yang menantang siswa agar belajar untuk belajar, bekerja sama dalam kelompok untuk mencari solusi bagi masalah yang nyata masalah ini diguakan untuk mengingatkan rasa keingintahuan serta kemampuan analitis dan inisiatif atas materi pelajaran. $P B L$ mempersiapkan siswa untuk berpikir kritis dan analisis dan untuk mencari dan menggunakan sumber pembelajaran yang sesuai. Pendapat tersebut diperkuat oleh Pusdiklatkes (2004) bahwa belajar berdasarkan masalah atau $P B L$ adalah suatu proses pembelajaran yang diawali dari masalah-masalah yang ditemukan dalam suatu lingkungan pekerjaan. $P B L$ adalah lingkungan belajar yang di dalamnya menggunakan masalah untuk belajar. Sebelum pembelajar mempelajari suatu hal, mereka diharuskan mengidentifikasi suatu masalah, baik yang dihadapi secara nyata maupun telaah kasus. Masalah diajukan sedemikian rupa sehingga para pembelajar menemukan kebutuhan belajar yang diperlukan agar mereka dapat memecahkan masalah tersebut.

\section{Karakteristik Metode $\boldsymbol{P B L}$}

Karakteristik metode $P B L$ adalah: (1) pembelajaran dimulai dengan pemberian masalah yang mengambang yang berhubungan dengan kehidupan nyata; (2) masalah dipilih sesuai dengan tujuan pembelajaran; (3) siswa menyelesaikan masalah dengan penyelidikan auntetik; (4) secara bersama-sama dalam kelompok kecil, siswa mencari solusi untuk memecahkan masalah yang diberikan; (5) guru bertindak sebagai tutor dan fasilitator; (6) siswa bertanggung jawab dalam memperoleh pengetahuan dan informasi yang bervariasi, tidak dari satu sumber saja; (7) siswa mempresentasikan hasil penyelesaian masalah da- 
lam bentuk produk tertentu. Produk dalam hal ini adalah berupa suatu pemrograman (Tan (2004:8); Hallinger dan Edwin (2007:89); Maggi Salvin dan Claire Howell (2004:4); Ibrahim et. al. (2009:155); Arends (2008:42)).

Menurut Pierce dan Jones (Rusman 2012:242) kejadian yang harus muncul dalam implementasi $P B L$ adalah: (1) keterlibatan yaitu mempersiapkan siswa untuk berperan sebagai pemecah masalah dengan bekerja sama, (2) inquiry dan investigasi yaitu mengeksplorasi dan mendistribusikan informasi, (3) performansi yaitu menyajikan temuan, (4) tanya jawab tujuannya untuk menguji keakuratan dari solusi, (5) refleksi terhadap pemecahan masalah.

Langkah-langkah metode problem $b a$ sed learning dalam penelitian mata pelajaran Pemrograman Sistem kendali PLC yaitu :

1. Memberikan permasalahan kepada siswa dimana permasalahan tersebut berhubungan dengan kehidupan sehari-hari

2. Guru mengorganisasikan siswa dalam beberapa kelompok

3. Guru membantu siswa mengorganisasikan tugas belajar sesuai dengan masalah

4. Siswa mengumpulkan pengetahuan dan melakukan percobaan sesuai dengan pemecahan masalah yang diberikan

5. Siswa mengembangkan dan menyajikan hasil karya yang berupa suatu program.

(Arends (2008:57); Amir (2009:24); Fogarty dalam Rusman(2012:243); Maastricht dalam Erik dan Anette(2003:659).

Menurut Maggi dan Claire (2004:6869) ada beberapa cara untuk menyajikan suatu masalah yang dapat menarik minat siswa sehingga proses pembelajaran tidak monoton dan membosankan. Beberapa cara tersebut yaitu meliputi:

1. Dimulai dengan memberikan sebuah masalah yang sesuai dengan pengetahuan dasar siswa sehingga akan menumbuhkan rasa antusias siswa tersebut.

2. Menyajikan sebuah masalah yang mampu menggali rasa keingintahuan siswa, misalnya sebuah masalah yang berkaitan dengan kehidupan sehari-hari.

3. Masalah yang disajikan masih berupa teka-teki yang harus dipecahkan

4. Pastikan bahwa penyampaian masalah tersebut menarik minat siswa.
5. Masalah yang diangkat sebaiknya berkaitan dengan kehidupan nyata.

$P B L$ merupakan suatu metode pembelajaran yang mempunyai banyak kelebihan dan kelemahan. kelebihan $P B L$ adalah sebagai berikut: (a) pemecahan masalah dalam $P B L$ cukup bagus untuk memahami isi pelajaran; (b) pemecahan masalah berlangsung selama proses pembelajaran menantang kemampuan siswa serta memberikan kepuasan kepada siswa; (c) $P B L$ dapat meningkatkan aktivitas pembelajaran; (d) membantu proses transfer siswa untuk memahami masalah-masalah dalam kehidupan sehari-hari; (e) membantu siswa mengembagkan pengetahuannya dan membantu siswa untuk bertanggungjawab atas pembelajarannya sendiri; (f) membantu siswa untuk memahami hakekat belajar sebagai cara berfikir bukan hanya sekedar mengerti pembelajaran oleh guru berdasarkan buku teks; (g) $P B L$ menciptakan lingkungan belajar yang menyenangkan dan disukai siswa; (h) memungkinkan aplikasi dalam dunia nyata; dan (i) merangsang siswa untuk belajar secara kontinu.

Kelemahan $P B L$ adalah sebagai berikut: (a) apabila siswa mengalami kegagalan atau kurang percaya diri dengan minat yang rendah mala siswa enggan untuk mencoba lagi; (b) $P B L$ membutuhkan waktu yang cukup untuk persiapan; dan (c) pemahaman yang kurang tentang mengapa masalah-masalah yang dipecahkan maka siswa kurang termotivasi untuk belajar. (Sanjaya (2008:221); Todd dalam Zabit (2010:23).

\section{Metode Demonstrasi}

Pembelajaran konvesional adalah pembelajaran yang dilakukan oleh guru pada umumnya. Metode pembelajaran yang telah diterapkan guru dalam melakukan pembelajaran PLC bisa dikatakan dengan metode pembelajaran demonstrasi.

Metode demonstrasi merupakan metode pembelajaran yang digunakan guru dalam menyampaikan materi pembelajaran kepada siswa dengan cara memperagakan atau mempertunjukkan secara sistematis suatu proses dengan prosedur yang harus dipelajari secara benar yang disertai dengan penjelasan. Dalam pelaksanaan nyata metode demonstrasi, siswa dapat mengamati dan memperhatikan apa yang diperlihatkan dan diperagakan guru se- 
lama pembelajaran berlangsung. untuk lebih profesional serta demi keberhasilan proses pembelajaran siswa (Syaiful Bahri Djamarah dan Azwan Zain (2006:90; Sharon E Smaldino, Deborah L Lowther dan James D Russel (2007:25); Sugihartono dkk (2007:83)).

\section{Motivasi Belajar}

Beberapa definisi dari para ahli mengenai motivasi secara garis besar mengandung makna yang hampir sama. Motivasi adalah sesuatu perubahan energi yang terdapat pada diri siswa yang mendorong siswa ingin melakukan hal yang ingin dicapai, sesuatu yang membuat siswa tersebut tetap ingin melakukannya dan menyelesaikan tugas-tugas akademik (Woolfolk (2007:372); McLean (2009:7); David Yundai dan Robert J. Sternberg (2004:11); MC.Donald dalam Oemar Hamalik (2007:78); Hamzah B. Uno (2011:8); Ford dalam Alderman (2004:18)).

Disarikan dari Sardiman AM (2012:83), Hamzah B. Uno (2011:23), Syaiful Bahri Djamarah (2011:149), alderman dalam Wang (2001) indikator untuk mengukur motivasi belajar siswa pada penelitian ini meliputi: (1) Ketekunan dalam belajar; (2) Ulet dalam menghadapi kesulitan; (3) Minat dan ketajaman perhatian dalam belajar; (4) Keinginan berhasil dalam belajar; (5) Mandiri dalam belajar; dan (6) reward/pujian/penghargaan.

\section{Hasil Belajar}

Hasil belajar adalah ukuran atau tingkat keberhasilan yang dapat dicapai oleh seorang siswa berdasarkan pengalaman yang diperoleh setelah dilakukan evaluasi berupa tes dan biasanya diwujudkan dengan nilai atau angkaangka tertentu serta menyebabkan terjadinya perubahan kognitif, afektif, maupun psikomotorik (Dimyati \& Mudjiono (2009:250); Nana Sudjana (2010:22)).

Kawasan kognitif, afektif, dan psikomotor sebagai hasil belajar diformulasikan oleh Bloom dan kawan-kawan (1956:7) di mana setiap aspek mempunyai tujuan kependidikan. Kawasan kognitif mencakup tujuan kependidikan yang berhubungan dengan pengingatan atau pengenalan tentang pengetahuan dan pengembangan keterampilan dan kemampuan intelektual. Kawasan afektif mencakup tujuan kependidikan yang mendeskripsikan perubahan dalam ketertarikan, si- kap, nilai, serta pengembangan apresiasi. Kawasan psikomotor meliputi hasil belajar yang berkaitan dengan manipulasi dan keterampilan gerak anggota badan.

Dalam penelitian ini diukur hasil belajar dengan taksonomi Bloom yang telah direvisi oleh Anderson dan Krathwohl. Dengan demikian, yang dimaksud hasil belajar dalam penelitian ini adalah tingkat keberhasilan yang dapat dicapai oleh seorang siswa berdasarkan pengalaman yang diperoleh setelah dilakukan evaluasi berupa tes yang menyebabkan terjadinya perubahan yang meliputi remember (mengingat), understand (memahami), apply (menerapkan), analyze (menganalisis), evaluate (mengevaluasi), create (mencipta). Selain itu juga dilihat dengan penilaian praktikum.

\section{Mata Pelajaran Pemrograman Sistem Ken- dali PLC}

Mata pelajaran pemrograman sistem kendali PLC adalah mata pelajaran yang masuk dalam kelompok produktif kompetensi keahlian elektronika industri di SMK. Standar kompetensi yang digunakan adalah Memprogram peralatan sistem pengendali elektronik yang berkaitan dengan I/O berbantuan PLC dan komputer. Dalam mata pelajaran ini, peserta didik harus menguasai kompetensi dasar sebagai berikut :

1) Mendiskripsikan ladder diagram pada pemrograman PLC

2) Memprogram PLC dengan menggunakan konsole dan komputer

3) Menggunakan bahasa pemrograman yang dapat berinteraksi dengan I/O pada sistem komputer

4) Mengintalasi sistem pengendali elektronik berbantuan PLC dan komputer dengan sensor, transduser dan penggerak (aktuator)

5) Mengoperasikan sistem pengendali elektronik berbantuan PLC dan komputer dengan sensor, transduser dan penggerak (aktuator)

6) Menguji kerja sistem pengendali elektronik berbantuan PLC dan komputer dengan sensor, transduser dan penggerak (aktuator)

7) Membuat dokumentasi hasil pemrograman peralatan sistem pengendali elektronik yang berkaitan dengan I/O bantuan PLC dan komputer. 
Programable Logic Controler (PLC) adalah komputer elektronik yang mudah digunakan (user friendly) yang memiliki fungsi kendali untuk berbagai tipe dan tingkat kesulitan yang beraneka ragam. PLC dapat didesain untuk pemakaian di lingkungan industri, dimana sistem ini menggunakan memori yang diprogram untuk penyimpanan secara internal instruksi-instruksi yang mengimplementasikan fungsi-fungsi spesifik seperti logika, urutan, pewaktuan, pemecahan, pencacahan, dan operasi aritmatik untuk mengontrol mesin. Simulator yang dapat digunakan sebagai simulasi plant yang diangkat sebagai permasalahan dalam dunia nyata adalah $C x$ Programmer. Dengan Cx Programmer dan metode problem based learning dapat membantu siswa menyelesaikan permasalahan dalam program sistem kendali PLC melalui diskusi serta kolaborasi.

\section{METODE PENELITIAN}

\section{Jenis Penelitian}

Jenis penelitian ini menggunakan pendekatan kuantitatif, karena dalam menganalisis data menggunakan data-data numerikal atau angka yang diolah dengan metode statistik, setelah diperoleh hasilnya, kemudian dideskripsikan dengan menguraikan kesimpulan yang didasari oleh angka yang diolah dengan metode statistik tersebut.

\section{Waktu dan Tempat Penelitian}

Penelitian ini dilakukan di SMK N 3 Wonosari yang berlokasi di Jl Pramuka Tawarsari wonosari Gunung Kidul. Waktu penelitian dilaksanakan pada semester genap tahun ajaran 2012/2013 tepatnya pada bulan Februari 2013 sampai dengan April 2013.

\section{Populasi dan Sampel Penelitian}

Populasi penelitian ini adalah siswa kelas XI dengan kompetensi keahlian teknik elektronika industri. Di SMK Negeri 3 Wonosari pada tahun ajaran 2012/2013 kelas XI untuk kompetensi keahlian teknik elektronika industri terbagi menjadi empat kelas, yaitu XI EI 1, EI 2, EI 3 dan EI 4.

\section{Prosedur}

Desain penelitiannya adalah quasi experiment. Quasi experiment merupakan eksperimen yang mempunyai unsur perlakuan, pretest, dan posttest tetapi tidak mengambil sampel secara random. Pembandingan tergantung pada kelompok-kelompok non-ekuivalen (Blessing \& Chakrabarti, 2009 :266). Desain quasi eksperiment yang digunakan adalah non equivalent control group design karena tidak mengacak kelas-kelas yang telah ada di tempat penelitian sehingga kelompok yang dibandingkan mengambil dari kelas-kelas yang telah ada.

Desain ini melibatkan dua kelas eksperimen dan satu kelas kontrol. Kelas eksperimen menggunakan metode $P B L$ dan kelas kontrol menggunakan metode pembelajaran yang telah diterapkan. Sebelum penelitian dilaksanakan, dilakukan pengukuran motivasi belajar siswa dengan cara memberikan angket motivasi belajar pada masing-masing siswa. Sebelum diberikan perlakuan dalam bentuk metode pembelajaran ketiga kelompok diberi pretest dan setelah diberikan perlakuan metode pembelajaran kedua kelompok diberi posttest untuk mengetahui hasil belajar siswa. Desain penelitian Pretest-Postest Control Group Design sebagai berikut:

Tabel 2.

\begin{tabular}{lccc}
\hline \multicolumn{1}{c}{ Kelompok } & Pre-Test & Perlakuan & Post-Test \\
\hline Eksperimen 1 & O1 & X1 & O2 \\
Eksperimen 2 & O1 & X1 & O2 \\
Kontrol & O1 & X2 & O2 \\
\hline
\end{tabular}

Keterangan:

O1 : tes awal (sebelum perlakuan) pada kelas eksperimen dan kelas kontrol

O2 : tes akhir (setelah perlakuan) pada kelas eksperimen dan kelas kontrol

$\mathrm{X} 1$ : pembelajaran dengan metode $P B L$ pada kelas eksperimen

X2 : pembelajaran dengan metode konvensional pada kelas kontrol

Sedangkan desain penelitian untuk hasil belajar pada praktik adalah sebagai berikut. 
Tabel 3.

\begin{tabular}{cccc}
\hline Kelompok & Pre-Test & Perlakuan & Post-Test \\
\hline Eksperimen 1 & - & $\mathrm{X} 1$ & $\mathrm{O} 2$ \\
Eksperimen 2 & - & $\mathrm{X} 1$ & $\mathrm{O} 2$ \\
Kontrol & - & $\mathrm{X} 2$ & $\mathrm{O} 2$ \\
\hline
\end{tabular}

Keterangan:

O2 : tes akhir (setelah perlakuan) pada kelas eksperimen dan kelas kontrol

$\mathrm{X} 1$ : pembelajaran dengan metode $P B L$ pada

kelas eksperimen

$\mathrm{X} 2$ : pembelajaran dengan metode demonstrasi pada kelas kontrol

Tabel 4. Kontrol validitas

\begin{tabular}{|c|c|c|}
\hline No. & Kontrol & Keterangan \\
\hline 1. & Unsur kematangan & $\begin{array}{l}\text { Siswa yang diberikan perlakuan harus mempunyai kemampuan tingkat } \\
\text { kecerdasan dan pengetahuan dasar pemrograman sistem kendali PLC } \\
\text { yang setara. Untuk memastikan hal tersebut, sebelumnya dilakukan } \\
\text { observasi terhadap kemampuan dan prestasi siswa pada setiap kelas yang } \\
\text { akan diberikan perlakuan. }\end{array}$ \\
\hline 2. & $\begin{array}{l}\text { Unsur peristiwa } \\
\text { dalam proses } \\
\text { pembelajaran }\end{array}$ & $\begin{array}{l}\text { Situasi dan kondisi dalam pembelajaran yang diberikan diupayakan sama } \\
\text { antara kelompok eksperimen dan kelompok kontrol. Waktu pemberian } \\
\text { perlakuan pada rentang waktu yang sama serta ruangan kelas yang } \\
\text { digunakan sama }\end{array}$ \\
\hline 3. & $\begin{array}{l}\text { Unsur subjek } \\
\text { penelitian }\end{array}$ & $\begin{array}{l}\text { Subjek penelitian pada kelompok eksperimen maupun kelompok kontrol } \\
\text { dipilih dari populasi yang karakteristiknya sama, menentukan kelompok } \\
\text { eksperimen dan kelompok kontrol secara random, serta membandingkan } \\
\text { kesamaan kemampuan awal pada ketiga kelompok sebelum diberikan } \\
\text { perlakuan dengan cara memberikan tes awal (pretest) }\end{array}$ \\
\hline 4. & $\begin{array}{l}\text { Unsur materi } \\
\text { perlakuan. }\end{array}$ & $\begin{array}{l}\text { Materi pembelajaran yang diberikan pada kelompok eksperimen dan } \\
\text { kelompok kontrol saat perlakuan diberikan mempunyai substansi isi } \\
\text { materi yang sama }\end{array}$ \\
\hline 5. & Unsur tes & $\begin{array}{l}\text { Tes hasil belajar yang diberikan pada kelompok eksperimen maupun } \\
\text { kelompok kontrol dikondisikan sama dan berupa tes objektif dan } \\
\text { penilaian praktikum }\end{array}$ \\
\hline 6. & $\begin{array}{l}\text { Pengaruh } \\
\text { "hawthrone" }\end{array}$ & $\begin{array}{l}\text { Agar subjek penelitian pada kelompok eksperimen maupun kelompok } \\
\text { kontrol tidak berbuat secara tidak wajar, maka selama pelaksanaan } \\
\text { pemberian perlakuan, subjek penelitian tidak diberi tahu bahwa mereka } \\
\text { sedang menjadi objek penelitian }\end{array}$ \\
\hline 7. & Unsur mortalitas & $\begin{array}{l}\text { Selalu dilakukan pencatatan terhadap kehadiran siswa dengan melakukan } \\
\text { presensi kehadiran serta selalu mengkondisikan jumlah siswa yang } \\
\text { mengikuti pembelajaran sampai adanya evaluasi dalam kondisi dan } \\
\text { keadaan jumlah yang terkontrol guna mencegah terdapatnya unsur } \\
\text { mortalitas }\end{array}$ \\
\hline
\end{tabular}

\section{Teknik dan Instrumen Pengumpulan Data}

Adapun teknik pengumpulan data yang digunakan dalam penelitian ini yaitu tes dan angket motivasi siswa.

1) Tes hasil belajar, digunakan untuk mengetahui hasil belajar siswa.

Instrumen yang digunakan dalam penelitian ini berupa instrumen soal test dalam bentuk pilihan ganda dengan empat pilihan jawaban. Untuk setiap butir soal, jawaban yang benar diberi skor 1 dan jawaban yang salah diberi skor 0 . Selain tes pilihan ganda, hasil belajar siswa juga diperoleh dari penilaian praktik. Penilaian praktek ini berupa penilaian pada persiapan kerja, proses, hasil kerja, dan sikap kerja siswa.

2) Angket motivasi belajar, digunakan untuk mengetahui motivasi belajar siswa. 


\section{Teknik Analisis Data}

Analisis data yang dilakukan dalam penelitian ini adalah: (1) Uji Kesamaan Kemampuan Awal; (2) Statistika Deskriptif; (3) Uji Prasyarat analisis; (4) Uji Hipotesis dengan Ttest; (5) Uji Hipotesis dengan ANAVA dua jalan.

\section{HASIL PENELITIAN DAN PEMBAHASAN}

Sebelum penelitian dilaksanakan, langkah pertama yang dilakukan yaitu menguji kemampuan awal subjek penelitian dengan melakukan pretest guna memperoleh data awal kemudian dilakukan pengujian keseimbangan sampel yang akan digunakan untuk penelitian. Sebelum melakukan uji hipotesis harus dilakukan uji prasyarat terlebih dahulu. Berikut ini adalah ringkasan hasil uji prasyarat data sebelum dan setelah diberi perlakuan, yang menunjukkan bahwa data memnuhi prasyarat analisis.

Tabel 5. Ringkasan hasil uji prasyarat data sebelum dan sesudah perlakuan

\begin{tabular}{cc}
\hline Data & Keputusan \\
\hline Pretest & Kemampuan awal sama \\
\hline \multicolumn{2}{c}{ Prasyarat analisis } \\
\hline pretest & Normal dan homogen \\
postest & Normal dan homogen \\
Motivasi belajar & Normal dan homogen \\
\hline
\end{tabular}

Analisis data dalam penelitian ini menggunakan statistik parametrik dengan menggunakan Uji-t dan analisis varians (ANAVA) dua jalan dan dilanjutkan dengan uji Scheffe. Analisis varians dua jalan digunakan untuk menguji perbedaan dan interaksi variabel bebas metode pembelajaran dan motivasi belajar siswa terhadap variabel terikat hasil belajar mata pelajaran pemrograman sistem kendali PLC.

Tabel 6 menunjukkan bahwa $p(0,000)<$ 0,05 . Sehingga dapat disimpulkan bahwa Ho ditolak dan Ha diterima, yaitu perbedaan hasil belajar siswa pada mata pelajaran pemrograman sistem kendali PLC antara siswa yang diberi pembelajaran dengan metode $P B L$ de- ngan siswa yang diajar dengan metode pembelajaran demonstrasi.

Tabel 6. Rangkuman Hasil Uji T Data Hasil Belajar

\begin{tabular}{|c|c|c|c|}
\hline \multicolumn{2}{|c|}{ Hasil Belajar } & \multirow{2}{*}{$\begin{array}{l}\text { Sig } \\
0,00\end{array}$} & \multirow{3}{*}{$\begin{array}{c}\begin{array}{c}\text { Keputusan } \\
\text { Uji }\end{array} \\
\text { Terdapat } \\
\text { perbedaan }\end{array}$} \\
\hline Hasil & Kelas & & \\
\hline Belajar & $\begin{array}{l}\text { Eksperimen } \\
\text { (1) dengan } \\
\text { kelas Kontrol }\end{array}$ & & \\
\hline & $\begin{array}{l}\text { Kelas } \\
\text { Eksperimen } \\
\text { (2) dengan } \\
\text { kelas Kontrol }\end{array}$ & 0,00 & $\begin{array}{c}\text { Terdapat } \\
\text { perbedaan }\end{array}$ \\
\hline \multirow{3}{*}{$\begin{array}{c}\text { Hasil } \\
\text { Praktik }\end{array}$} & Kelas & 0,00 & Terdapat \\
\hline & $\begin{array}{l}\text { Eksperimen } \\
\text { (1) dengan } \\
\text { kelas Kontrol }\end{array}$ & & perbedaan \\
\hline & $\begin{array}{l}\text { Kelas } \\
\text { Eksperimen } \\
\text { (2) dengan } \\
\text { kelas Kontrol }\end{array}$ & 0,00 & $\begin{array}{l}\text { Terdapat } \\
\text { perbedaan }\end{array}$ \\
\hline
\end{tabular}

Dari data hasil belajar siswa, menunjukkan bahwa hasil belajar siswa yang diajar dengan metode $P B L$ lebih tinggi dibandingkan dengan hasil belajar siswa yang diajar dengan metode pembelajaran demonstrasi $\left(\overline{\mathrm{X}} \mathrm{A}_{1(1)}=\right.$ $81,60>\overline{\mathrm{X}} \mathrm{A}_{2}=69,87 ; \overline{\mathrm{X}} \mathrm{A}_{1(2)}=82,32>\overline{\mathrm{X}}$ $\left.\mathrm{A}_{2}=69,87\right)$. Hasil belajar siswa pada praktik yang diajar dengan metode $P B L$ juga lebih tinggi dibandingkan dengan hasil belajar siswa yang diajar dengan metode pembelajaran konvensional ( $\overline{\mathrm{X}} \mathrm{A}_{1(1)}=85,87>\overline{\mathrm{X}} \mathrm{A}_{2}=72,24$; $\left.\overline{\mathrm{X}} \mathrm{A}_{1(2)}=86,71>\overline{\mathrm{X}} \mathrm{A}_{2}=72,24\right)$.

Selain itu, terdapat perbedaan gain hasil belajar antara siswa yang diajar dengan metode $P B L$ dengan siswa yang diajar dengan metode pembelajaran demonstrasi diterima. Rata-rata gain hasil belajar metode $P B L$ lebih tinggi dibandingkan dengan rata-rata gain hasil belajar metode pembelajaran demonstrasi $\left(\overline{\mathrm{X}} \mathrm{A}_{1(1)}=34,64>\overline{\mathrm{X}} \mathrm{A}_{2}=22,19 ; \overline{\mathrm{X}}\right.$ $\left.A_{1(2)}=31,01>\bar{X} A_{2}=22,19\right)$. Hal ini menunjukkan bahwa metode $P B L$ lebih unggul dibandingkan dengan metode pembelajaran demonstrasi.

Pada metode $P B L$ bersifat student centered. Pada metode pembelajaran ini guru 
memberikan tugas berupa masalah yang masih mengambang kemudian siswa mencari solusi untuk memecahkan masalah yang diberikan. Dari berbagai masalah yang telah diberikan kemudian siswa merumuskan masalah tersebut dan mencari pemecahannya. Dalam pemecahan masalah dilakukan dengan diskusi kelompok sehingga siswa dapat saling bertukar pikiran dan membagi ilmu dengan siswa lainya. Setelah masalah tersebut dapat dipecahkan dan dibuktikan ke dalam praktik, kemudian dilanjutkan dengan presentasi kelas. Pada presentasi ini akan terjadi diskusi dan pertukaran informasi kembali dalam kelompok satu kelas. Dari diskusi itu akan didapatkan pengalaman dan wawasan baru dan kadang ditemukan juga permasalahan permasalahan baru yang berkaitan untuk dipecahkan. Dalam pemecahan masalah ini siswa juga mencari pengetahuan sendiri karena peran guru hanya sebagai fasilitator bukan pentransfer pengetahuan.

Pada metode pembelajaran demonstrasi, guru menyajikan materi dari awal sampai akhir dan peran guru sangat dominan dalam kegiatan belajar mengajar. Sebelum kegiatan praktikum, guru memperagakan kepada siswa tentang suatu proses penggunaan intruksi pemrograman. Pada metode pembelajaran ini, kegiatan belajar belajar mengajar berpusat pada guru dan kurang memperhatikan keaktifan siswa. Peran siswa hanya sekedar memperhatikan apa yang didemonstrasikan oleh guru. Pada kegiatan praktik, siswa hanya melakukan praktik terencana sesuai dengan yang telah didemonstrasikan dan tertuang di dalam jobsheet.

Tabel 7. Rangkuman Hasil ANAVA Data Hasil Belajar

\begin{tabular}{|c|c|c|c|}
\hline & Hasil Belajar & $\begin{array}{l}\operatorname{Sig}(2- \\
\text { tailed })\end{array}$ & Keputusan Uji \\
\hline \multirow{2}{*}{$\begin{array}{c}\text { Hasil } \\
\text { Belajar }\end{array}$} & Kelas Eksperimen $(1) *$ kelas Kontrol & 0,674 & Tidak terdapat interaksi \\
\hline & Kelas Eksperimen $(2) *$ kelas Kontrol & 0,366 & Tidak terdapat interaksi \\
\hline \multirow{2}{*}{$\begin{array}{c}\text { Hasil } \\
\text { Praktik }\end{array}$} & Kelas Eksperimen $(1) *$ kelas Kontrol & 0,741 & Tidak terdapat interaksi \\
\hline & Kelas Eksperimen $(2) *$ kelas Kontrol & 0,725 & Tidak terdapat interaksi \\
\hline
\end{tabular}

Taraf signifikansi yang digunakan pada uji analisis varians dua jalan adalah sebesar 0,05 . Jika nilai $\mathrm{Sig}<0,05$ maka terdapat interaksi antara metode pembelajaran dan kategori motivasi terhadap hasil belajar, sebaliknya jika nilai Sig > 0,05 maka tidak terdapat interaksi antara metode pembelajaran dan kategori motivasi terhadap hasil belajar. Dengan demikian dapat disimpulkan bahwa tidak terdapat interaksi antara metode pembelajaran dan kategori motivasi belajar terhadap hasil belajar. Oleh karena tidak terjadi interaksi antara metode pembelajaran dan kategori motivasi belajar terhadap hasil belajar maka dapat dinyatakan bahwa pencapaian hasil belajar tidak dipengaruhi secara tidak signifikan oleh interaksi antara metode pembelajaran yang diterapkan dalam pembelajaran dengan motivasi belajar, artinya metode pembelajaran $P B L$ akan memberikan hasil belajar yang lebih tinggi dibandingkan dengan metode pembelajaran demonstrasi ditinjau dari siswa yang memiliki motivasi tinggi maupun rendah.

Dari analisis varians (ANAVA) dua jalan terlihat bahwa terdapat perbedaan hasil belajar antara siswa yang diajar dengan metode $P B L$ dengan siswa yang diajar dengan metode demonstrasi. Hasil analisis varians (ANAVA) tersebut kemudian dilanjutkan dengan uji Scheffe. Uji Scheffe dalam penelitian ini menggunakan bantuan program SPSS 16 For Windows. Selanjutnya rangkuman uji lanjut scheffe untuk untuk mengetahui perbedaan hasil belajar ditinjau dari motivasi tinggi dan rendah adalah sebagai berikut: 
Tabel 8. Rangkuman Hasil Analisis Varians Tahap Lanjut dengan Uji Scheffe

\begin{tabular}{|c|c|c|c|c|}
\hline Kelompok yang dibandingkan & & $P_{\text {Value }}$ & Kondisi & Keputusan Uji \\
\hline $\begin{array}{l}P B L(1) \text { dengan demonstrasi ditinjau dari siswa } \\
\text { yang memiliki motivasi tinggi }\end{array}$ & $\begin{array}{l}\text { Hasil } \\
\text { Belajar }\end{array}$ & 0,000 & $<0,05$ & $\begin{array}{l}\text { Terdapat } \\
\text { perbedaan }\end{array}$ \\
\hline $\begin{array}{l}P B L(2) \text { dengan demonstrasi ditinjau dari siswa } \\
\text { yang memiliki motivasi tinggi }\end{array}$ & & 0,000 & $<0,05$ & $\begin{array}{c}\text { Terdapat } \\
\text { perbedaan }\end{array}$ \\
\hline $\begin{array}{l}P B L(1) \text { dengan demonstrasi ditinjau dari siswa } \\
\text { yang memiliki motivasi rendah }\end{array}$ & & 0,002 & $<0,05$ & $\begin{array}{l}\text { Terdapat } \\
\text { perbedaan }\end{array}$ \\
\hline $\begin{array}{l}P B L(2) \text { dengan demonstrasi ditinjau dari siswa } \\
\text { yang memiliki motivasi rendah }\end{array}$ & & 0,002 & $<0,05$ & $\begin{array}{l}\text { Terdapat } \\
\text { perbedaan }\end{array}$ \\
\hline $\begin{array}{l}P B L(1) \text { dengan demonstrasi ditinjau dari siswa } \\
\text { yang memiliki motivasi tinggi }\end{array}$ & $\begin{array}{c}\text { Hasil } \\
\text { Praktik }\end{array}$ & 0,001 & $<0,05$ & $\begin{array}{c}\text { Terdapat } \\
\text { perbedaan }\end{array}$ \\
\hline $\begin{array}{l}P B L(2) \text { dengan demonstrasi ditinjau dari siswa } \\
\text { yang memiliki motivasi tinggi }\end{array}$ & & 0,001 & $<0,05$ & $\begin{array}{l}\text { Terdapat } \\
\text { perbedaan }\end{array}$ \\
\hline $\begin{array}{l}P B L(1) \text { dengan demonstrasi ditinjau dari siswa } \\
\text { yang memiliki motivasi rendah }\end{array}$ & & 0,001 & $<0,05$ & $\begin{array}{l}\text { Terdapat } \\
\text { perbedaan }\end{array}$ \\
\hline $\begin{array}{l}P B L(2) \text { dengan demonstrasi ditinjau dari siswa } \\
\text { yang memiliki motivasi rendah }\end{array}$ & & 0,002 & $<0,05$ & $\begin{array}{l}\text { Terdapat } \\
\text { perbedaan }\end{array}$ \\
\hline
\end{tabular}

Dari rangkuman hasil analisis varians (ANAVA) tahap lanjut dengan uji Scheffe diatas, maka dapat dijelaskan sebagai berikut.

a. Secara signifikan terdapat perbedaan hasil belajar antara siswa yang diajar dengan metode $P B L$ dengan siswa yang diajar dengan metode demonstrasi ditinjau dari siswa yang memiliki motivasi tinggi. Hasil belajar siswa yang diajar dengan metode $P B L$ lebih tinggi dibandingkan dengan hasil belajar siswa yang diajar dengan metode pembelajaran demonstrasi ditinjau dari siswa yang memiliki motivasi tinggi $\left(\overline{\mathrm{X}} \mathrm{A}_{1(1)} \mathrm{B}_{1}=84,64>\right.$ $\overline{\mathrm{X}} \mathrm{A}_{2} \mathrm{~B}_{1}=70,50 ; \overline{\mathrm{X}} \mathrm{A}_{1(2)} \mathrm{B}_{1}=84,64>\overline{\mathrm{X}}$ $\left.\mathrm{A}_{2} \mathrm{~B}_{1}=70,50\right)$. Hasil belajar siswa pada penilaian praktik yang diajar dengan metode $P B L$ juga lebih tinggi dibandingkan dengan hasil belajar siswa yang diajar dengan metode pembelajaran demonstrasi ditinjau dari siswa yang memiliki motivasi tinggi $\left(\overline{\mathrm{X}} \mathrm{A}_{1(1)} \mathrm{B}_{1}=88,30>\right.$ $\overline{\mathrm{X}} \mathrm{A}_{2} \mathrm{~B}_{1}=73,84 ; \overline{\mathrm{X}} \mathrm{A}_{1(2)} \mathrm{B}_{1}=89,08>\overline{\mathrm{X}}$ $\left.\mathrm{A}_{2} \mathrm{~B}_{1}=73,84\right)$.

b. Secara signifikan terdapat perbedaan hasil belajar antara siswa yang diajar dengan metode pembelajaran $P B L$ dengan siswa yang diajar dengan metode pembelajaran demonstrasi ditinjau dari siswa yang memiliki motivasi rendah. Hasil belajar siswa yang diajar dengan metode $P B L$ lebih tinggi dibandingkan dengan hasil belajar siswa yang diajar dengan metode pembelajaran demonstrasi ditinjau dari siswa yang memiliki motivasi rendah $\left(\overline{\mathrm{X}} \mathrm{A}_{1(1)} \mathrm{B}_{2}=80,00>\overline{\mathrm{X}}\right.$ $\mathrm{A}_{2} \mathrm{~B}_{2}=69,28 ; \overline{\mathrm{X}} \mathrm{A}_{1(2)} \mathrm{B}_{2}=80,00>\overline{\mathrm{X}}$ $\left.A_{2} B_{2}=69,28\right)$. Hasil belajar siswa pada nilai praktik yang diajar dengan metode $P B L$ juga lebih tinggi dibandingkan dengan hasil belajar siswa yang diajar dengan metode pembelajaran demonstrasi ditinjau dari siswa yang memiliki motivasi rendah $\left(\overline{\mathrm{X}} \mathrm{A}_{1(1)} \mathrm{B}_{2}=83,75>\overline{\mathrm{X}}\right.$ $\mathrm{A}_{2} \mathrm{~B}_{2}=70,75 ; \quad \overline{\mathrm{X}} \mathrm{A}_{1(2)} \mathrm{B}_{2}=84,33>\overline{\mathrm{X}}$ $\mathrm{A}_{2} \mathrm{~B}_{2}=70,75$ ).

Konsep pemecahan masalah pada metode $P B L$ dilakukan dengan cara diskusi kelompok. Metode $P B L$ lebih menekankan pada pertukaran pendapat dan berbagi pengalaman dalam pemecahan masalah. Siswa yang memiliki motivasi tinggi akan lebih tertarik untuk meng-explor pengetahuan dan berkeinginan untuk mengetahui suatu hal baru guna memecahkan masalah yang berhubungan dengan dunia nyata. Akan tetapi, kondisi tersebut tidak terjadi pada metode pembelajaran de- 
monstrasi yang selalu mengedepankan peran guru dari pada siswa. Meskipun siswa samasama memiliki motivasi rendah dalam belajar, akan tetapi hasil belajar yang dicapai berbeda. Perbedaan hasil belajar tersebut terjadi karena penggunaan metode yang berbeda pula, yakni metode $P B L$ dan metode pembelajaran demonstrasi. Siswa yang memiliki motivasi rendah yang diajar dengan metode $P B L$ lebih termotivasi untuk menelusuri dan mengexplor pengetahuan sendiri daripada siswa yang diajar dengan metode pembelajaran demonstrasi yang selalu mengedepankan peran guru dari pada siswa. Dalam metode pembelajaran demonstrasi ini peran guru lebih dominan, sehingga menyebabkan siswa kurang antusius mengikuti kegiatan belajar mengajar dan cenderung cepat bosan.

\section{SIMPULAN DAN SARAN}

\section{Simpulan}

Berdasarkan hasil penelitian, analisis data serta pembahasan maka dapat diambil kesimpulan sebagai berikut :

1. Terdapat perbedaan hasil belajar yang signifikan antara siswa yang diajar dengan metode $P B L$ dengan siswa yang diajar dengan metode pembelajaran demonstrasi. Hasil belajar siswa yang diajar dengan metode $P B L$ lebih tinggi dibandingkan dengan siswa yang diajar dengan metode pembelajaran demonstrasi. Peningkatan hasil belajar siswa yang diajar dengan metode $P B L$ lebih tinggi dibandingkan dengan peningkatan hasil belajar siswa yang diajar dengan metode pembelajaran demonstrasi.

2. Tidak terdapat pengaruh interaksi yang signifikan antara metode $P B L$ dan metode pembelajaran demonstrasi dengan motivasi belajar terhadap hasil belajar siswa. Dengan tidak adanya pengaruh interaksi dan melihat rerata hasil belajar yang diperoleh dari kedua metode pembelajaran tersebut dapat dikatakan bahwa metode $P B L$ dan metode pembelajaran demonstrasi sama-sama dapat meningkatkan hasil belajar, artinya kedua metode pembelajaran tersebut efektif diterapkan bagi siswa yang memiliki motivasi rendah. Namun, metode $P B L$ akan memberikan hasil belajar yang lebih tinggi dibandingkan dengan metode pembelajaran demonstrasi ditinjau dari siswa yang memiliki motivasi tinggi maupun rendah.

3. Terdapat perbedaan hasil belajar yang signifikan antara siswa yang diajar dengan metode $P B L$ dengan siswa yang diajar dengan metode pembelajaran demonstrasi ditinjau dari motivasi siswa. Ditinjau dari siswa yang memiliki motivasi tinggi, hasil belajar antara siswa yang diajar dengan metode Problem Based Learning lebih tinggi dibandingkan dengan siswa yang diajar dengan metode pembelajaran demonstrasi. Ditinjau dari siswa yang memiliki motivasi rendah, hasil belajar antara siswa yang diajar dengan metode $P B L$ lebih tinggi dibandingkan dengan siswa yang diajar dengan metode pembelajaran demonstrasi.

\section{Saran}

Berdasarkan kesimpulan hasil penelitian, maka implikasi hasil penelitian tersebut adalah sebagai berikut :

1. Bagi Guru, penerapan metode pembelajaran oleh seorang guru yang tepat akan memberikan dampak pada perolehan hasil belajar siswa yang baik dan maksimal. Meskipun hasil belajar yang baik dan maksimal tidak sepenuhnya ditentukan oleh penggunaan metode pembelajaran akan tetapi guru harus memahami metode pembelajaran baik secara konseptual maupun praktikal. Penelitian ini menunjukkan bahwa pemilihan penerapan metode pembelajaran yang sesuai akan lebih efektif dan maksimal dalam meningkatkan hasil belajar.

2. Bagi Institusi Pendidikan yaitu perguruan tinggi yang bertugas mencetak calon guru yang profesional dalam bidangnya, perguruan tinggi harus mampu membekali para calon guru dengan bagaimana cara menerapkan metode pembelajaran yang baik, tepat sasaran, dapat dipahami siswa serta sesuai dengan karakteritik siswa. Dengan demikian diharapkan tujuan pembelajaran dapat sepenuhnya dapat tercapai dengan baik.

Berdasarkan kesimpulan dan implikasi penelitian di atas, berikut adalah beberapa sa- 
ran untuk meningkatkan hasil belajar siswa, antara lain :

1. Guru

a. Sesuai dengan hasil penelitian, bagi guru yang akan mengajar siswa yang mempunyai motivasi rendah maupun motivasi tinggi pada mata pelajaran pemrograman sistem kendali PLC menggunakan metode Problem Based Learning dari pada metode konvensional, karena hasil belajar yang menggunakan metode Problem Based Learning lebih tinggi dibandingkan dengan hasil belajar metode pembelajaran konvensional.

b. Agar tujuan pembelajaran dapat tercapai dengan maksimal, maka guru dapat memilih metode pembelajaran dengan tepat serta sesuai dengan karakteristik siswa, karena jika tidak sesuai dengan karakteristik siswa maka tujuan pembelajaran tidak akan sepenuhnya dapat tercapai dengan maksimal. Hal lain yang harus diperhatikan guru dalam mengajar adalah guru harus dapat memotivasi siswa dalam belajar, sehingga siswa dapat belajar dengan baik, tekun dan memperoleh hasil belajar yang maksimal

\section{Sekolah}

Pihak sekolah diharapkan lebih memperhatikan sarana prasarana yang optimal untuk mendukung metode $P B L$ seperti penggadaan sumber belajar, komputer yang tersambung dengan internet, dan alat-alat yang mendukung kegiatan pembelajaran. Sarana prasarana tersebut digunakan siswa untuk mencari pengetahuan dan informasi, karena pengetahuan dan informasi siswa tidak hanya dari satu sumber saja.

3. Peneliti Selanjutnya

Kepada peneliti lain yang membaca penelitian ini dan bermaksud mengembangkan hasil temuan lebih lanjut, diharapkan dapat melakukan penelitian yang lebih baik dengan lebih banyak menggunakan sampel penelitian sehingga hasilnya akan lebih luas dan lebih terukur keakuratannya. Selain itu, diharapkan dapat melakukan penelitian untuk mata pelajaran produktif lainnya.

\section{DAFTAR PUSTAKA}

Alderman, M. K. (2004). Motivation for achievement: Possibilities for teaching and learning. New Jersey : Lawrence Erlbaum Associates, Inc., Publishers.

Amir, M. Taufiq. (2009). Inovasi pendidikan melalui problem based learning. Bagaimana pendidik memberdayakan pemelajar di era pengetahuan. Jakarta: Kencana Prenada Media Group.

Arends, Richard. I. (2008). Belajar untuk mengajar. Edisi ke tujuh alih bahasa oleh helly prayitno dan sri mulyantani prayitnodari judul learning to teach. Seven edition. Yogyakarta : Penerbit Pustaka Pelajar.

Barbara. B. Levin. (2001). Energizing teacher education and profesional development with problem based learning. United States: ASCD.

Blessing, L.T.M., \& Chakrabarti, A.. (2009). DRM, A design research methodology. London: Springer.

Bloom, B (ed). (1956). Taxonomy of educational objectives: The classification of educational goals. Handbook 1 cognitive domain. New York: David McKay Company.

Dai, D.Y., \& Sternberg, R. J. (2004). Motivation, emotion, and cognition: Integrative perspectives on intellectual development and functioning. New Jersey : Lawrence Erlbaum Associates, Inc., Publishers.

Dimyati dan Mudjiono. (2009). Belajar dan pembelajaran. Jakarta: Rineka Cipta.

Erik, D.G., \& Anette, K. (2003). Characteristics of problem-based learning. International Journal Engng Ed., 19(5), 657-662.

Glazer, E. (2001). Problem based instruction from emerging perspectives on learning, teaching, and technology. Diambil pada tanggal 31 Mei 2013, dari http://epltt.coe.uga.edu/index.php?title= Problem Based Instruction

Hamzah. B. Uno. (2011). Teori motivasi dan pengukurannya. Jakarta: Bumi Aksara. 
Heinich, R., Molenda, M., \& Russel, J.,D. (1989). Instructional and new technologies of instruction. New York: Macmillan, Inc.

Ibrahim, B., Erdal, S., Mustafa, S. (2009). The effect of problem-based leraning instruction on university students' perfermance of conceptual and quantitative problems in gas concepts. Eurosia Jurnal of Mathematics, Science \& Technology Education, 5(2), 153-156

Linda, T. \& Sara, S. (2002). Problems as possibilities: problem-based learning for $\mathrm{K}-16$ education. ASCD.

Maggi, S. \& Claire H.M. (2004). Foundations of problem-based learning. New York: Open University Press.

McLean, Alan. (2009). Motivating every learner. London: Sage.

Nana Sudjana. (2010). Penilaian hasil proses belajar mengajar. Bandung: PT. Remaja Rosdakarya.

Philip, H. \& Edwin, M.B. (2007). A problembased approach for management education. The Netherlands: Springer.

Pusdiklatkes, (2004). Bahan pembelajaran problem based learning (belajar berdasar masalah). Diambil pada tanggal 24 Desember 2012, dari http://www.lrckesehatan.net/cdroms ht $\underline{\mathrm{m} / \mathrm{pbl} / \mathrm{pbl} . \mathrm{htm}}$

Rusman. (2012). Model-model pembelajaran mengembangkan profesional guru. Jakarta : Raja Grafindo Persada.

Sardiman, A. M. (2012). Interaksi \& motivasi belajar mengajar. Cetakan ke-21. Jakarta: Rajawali Pers.

Smaldino, S.E., Lowther, D.L. \& Russell, J.D. (2007). Instructional technology and media for learning $\left(9 t^{h} e d\right)$. Colombus: Merrill.
Sugihartono, dkk. (2007). Psikologi pendidikan. Yogyakarta: UNY Press.

Suyono dan Hariyanto. (2011). Belajar dan pembelajaran. Bandung: PT. Remaja Rosdakarya.

Syaiful Bahri Djamarah dan Azwan Zain. (2006). Strategi belajar mengajar. Jakarta: Rineka Cipta.

Syaiful Bahri Djamarah. (2011). Psikologi belajar. Jakarta: Rineka Cipta.

Tan, Oon-Seng. (2003). Problem based learning innovation: Using problems to power learning in the 21 st century. Cengage Learning.

Tan, Oon-Seng. (2004). Enhancing thingking through problem-based learning approaches. Cengage Learning.

Trianto. (2009). Mendesain model pembelajaran inovativ-progresif. Jakarta: Kencana Prenada Media Group.

Oemar, Hamalik. (2007). Proses belajar mengajar. Bandung: Bumi Aksara.

Wang, S. (2001). Motivation: General overview of theories from Emerging perspectives on learning, teaching, and technology. Diambil pada tanggal 24 Desember 2012, dari http://epltt.coe. uga.edu/index.php?title=Motivation

Wina, Sanjaya. (2008). Strategi pembelajaran. Jakarta: Kencana prenada Media.

Winataputra, U. S., et al. (2008). Teori belajar dan pembelajaran. Jakarta: Penerbit Universitas Terbuka.

Woolfolk, Anita. (2007). Educational psychology. Boston: Pearson.

Zabit, M.N.M, (2010). Problem-based learning on students' critical thinking skills in teaching business education in malaysia: A literature review. American Journal of Bussiness Education, 3(6). 